WORD OF WELCOME BY THE CHAIRMAN OF THE LOCAL ORGANIZING COMMITTEE. PROFESSOR J. SMAK

'Obywatelu Prezesie Rady Ministrów, Monsieur le Président de l'Union Astronomique Internationale, Distinguished Guests, Dear Members of the International Astronomical Union, Ladies and Gentlemen,

W imieniu Lokalnego Komitetu Organizacyjnego Nadzwyczajnego Kongresu Międzynarodowej Unii Astronomicznej mam zaszczyt powitać wszystkich naszych dostojnych i drogich gości przybyłych na ten Kongres, a w szczególności na dzisiejsze Uroczyste Otwarcie i Sesję Plenarną, związaną z obchodami 500-letniej Rocznicy Urodzin Mikołaja Kopernika.

On behalf of the Local Organizing Committee for the Extraordinary General Assembly of the International Astronomical Union I have the privilege to welcome all our distinguished and dear guests which came to participate in the Assembly, and particularly in this General Commemorative Session connected with the celebrations of the Quincentenary of Nicolaus Copernicus.

I have the honour now to request the Chairman of the Council of Ministers of the Polish People's Republic, Mr Piotr Jaroszewicz, to deliver his address.

Obywatelu Premierze, proszę o zabranie głosu.'

\title{
ADDRESS BY THE CHAIRMAN OF THE COUNCIL OF MINISTERS OF THE POLISH PEOPLE'S REPUBLIC, MR P. JAROSZEWICZ
}

'Mr President of the International Astronomical Union, Distinguished Members of the Extraordinary Session of the Union's General Assembly,

Among the many international meetings of scientists, the importance of which in the world of today can hardly be overestimated, the session we have just inaugurated undoubtedly assumes special significance. This is so, on account of the high rank astronomy enjoys as a branch of science, the high esteem for your Union in the international scientific community, and by no means incidental time and place of this meeting which crowns the international observances of Mikolaj Kopernik's 500 th birthday anniversary on his native soil.

Astronomy is one of the most prominent and one of the oldest branches of science, yet it is abundant in new great discoveries of surprisingly large scale, constantly affecting man's cognitive abilities, world outlook and civilization. Just as in remote times astronomic knowledge had laid the ground for the development of navigation, due to which new seas and lands were discovered, our mother planet Earth became better known and its place in the universe was defined, today astronomy paves man's way in the cosmic space, fulfills his ages-long aspirations to fly in the air, steals away from Nature its greatest secrets.

Time calendar, in common use by all mankind today, owes its existence to astronomy. We use the calendar not only to measure time. We also use it to mark down the happenings which make up the history of humanity, which shape the awareness of successive generations and are the traces of their common heritage: development and progress.

On one page in this calendar the birthday of a genius was also marked down, a genius whose discovery opened a new chapter in the history of astronomy, a mile-stone in the history of human cognition, thus laying the foundations for a major breakthrough in human awareness and intellectual culture.

More than three hundred years had to elapse for that basic truth to become fully recognized, to become an element of education and popular awareness. The lapse of time, however, did not diminish the enormity, creative power and validity of Copernican traditions in present-day world; quite the opposite, it enhanced them. These traditions are alive today due to the scientific discoveries and the continually valid patterns of Kopernik as a man, as an explorer looking for truth everywhere, as a Pole and citizen who combined his service of the country with service of humanity.

The strength and significance of Copernican traditions are particularly notable in Poland.

The memory and loyalty to the legacy of Polish science and culture played an essential role in the 